\title{
Evaluation of Women's Empowerment in a Community-Based Human Papillomavirus Self- Sampling Social Entrepreneurship Program (Hope Project) in Peru: Mixed-Method Study
}

Michelle B. Shin ( $\sim$ mbyshin@uw.edu )

University of Washington

Patricia J. Garcia

Cayetano Heredia University

Mary Elizabeth Dotson

Duke University

María Valderrama

Cayetano Heredia University

Marina Chiappe

Cayetano Heredia University

Nimmi Ramanujam

Duke University

Marlee Krieger

Duke University

Kristjana Ásbjörnsdóttir

University of Iceland

\section{Ruanne V. Barnabas}

University of Washington

Sarah J. Iribarren

University of Washington

Sarah Gimbel

University of Washington

\section{Research Article}

Keywords: empowerment, social entrepreneurship, human papillomavirus (HPV), Relational Leadership Theory

Posted Date: August 31st, 2021 
DOI: https://doi.org/10.21203/rs.3.rs-826680/v1

License: (c) (1) This work is licensed under a Creative Commons Attribution 4.0 International License. Read Full License 


\section{Abstract}

Background: Understanding the community women's sense of relational and financial empowerment in the social entrepreneurship context could be the key to developing a sustainable pathway to scale-up community-based human papillomavirus (HPV) self-sampling programs in low-resource settings. The Hope Project, social entrepreneurship from Peru, trains women (Hope Ladies) to promote HPV selfsampling among other women in their communities. This study aims to evaluate the Hope Ladies' relational/financial empowerment after participating in the program.

Methods: We used a parallel mixed-method design. The Hope Ladies participated in semi-structured indepth interviews ( $n=20)$ and an eight-questions five-point Likert scale survey that evaluated their relational $(n=19) /$ financial $(n=17)$ empowerment after participating in the social entrepreneurship. The interview and the survey questions were developed using validated empowerment frameworks, indicators, and theory: 1) Kabeer's conceptual framework, 2) International Center for Research on Women (ICRW)'s economic empowerment indicators, and 3) the Relational Leadership Theory (RLT), respectively. Deductive content analysis was used to evaluate the interviews with pre-determined codes and categories of empowerment. Descriptive statistics were used to analyze the survey results.

Results: All Hope Ladies reported experiencing empowerment in the social entrepreneurship. Interviews: The women reported challenges and improvement in three categories of empowerment: 1) resources (balancing the roles between the household and working as a Hope Lady, camaraderie with other Hope Ladies, recognition from the community as a resource); 2) agency (improved ability to express themselves, increased knowledge about reproductive health, ability to speak out against male-dominant culture and fear of cervical cancer-related stigma); and 3) achievement (increased economic assets, improved ability to make financial decisions from increased supplemental income, widened social network and capital, and technology skills development). Survey. All (100\%) agreed/totally agreed an increase in social contacts, increased unaccompanied visits to a healthcare provider (86\%), improved confidence in discussing reproductive topics (100\%), improved ability to make household decisions about money (57\% pre-intervention vs. $92 \%$ post-intervention).

Conclusions: The Hope Ladies' reported improved relational/financial empowerment through participating in community-based social entrepreneurship. More studies are needed to elucidate the relationship between empowerment and worker retention/performance to inform the scale-up of HPV selfsampling social entrepreneurship.

\section{Background}

Social entrepreneurship is a highly theorized field of knowledge that has rapidly emerged in recent decades. As such, there has been a proliferation of systematic reviews (1, 2), bibliometric studies (3-5), and other endeavors (6-8) to explore social entrepreneurship and other efforts to set forth research direction and framework for the future (9-11). Social entrepreneurship could be understood as a 
phenomenon (12) or organizations (1) that leverage economic activities or innovative business models with the mission of creating or implementing positive social change (13-17) rather than personal or shareholder wealth $(18,19)$.

Social entrepreneurship activities in economically emerging countries have often taken the form of microfinance or microcredit programs designed to advance women's economic development (20). Women working in health-oriented social entrepreneurship programs seek to become financially selfsufficient by promoting health or health products rather than being dependent on or being employed by an organization (21). Women-driven social entrepreneurship programs have been shown to empower the entrepreneurs, not only economically, but by widening their social network in their communities, giving them technical skills with earning potential, and challenging the gender norm and their status in families and society (22). Kabeer explains women's empowerment as a process of changes, "by which those who have been denied the capacity for choice gain this capacity" that entails the inter-related, "indivisible" dimensions of resources (pre-conditions), agency (process), and achievements (outcomes) $(23,24)$. She also emphasizes that women are embedded, active members within their society, and hence, their empowerment can create social change in those societies where women lack equal power (24). Some scholars support the claims that the elements of empowerment are inherently and essentially embedded in the for-profit social entrepreneurship models (25-27).

The Hope Project is a social entrepreneurship initiative started as a pilot at the Universidad Peruana Cayetano Heredia in 2015 to evaluate the feasibility and acceptability of human papillomavirus (HPV) self-sampling promoted by women from within the community to improve cervical cancer screening (28). After the successful pilot, the program officially began in November 2018 with two components: commercial and social. The commercial component offers HPV self-sampling kits and testing with CareHPV® (Quiagen) online to high- and middle-income women in Peru for a higher price (150 Peruvian Soles [PEN], 43 US Dollars [2020 USD]) to create a sustainable platform to offer subsidized testing to women with fewer resources. In the social component, which is currently located in Ventanilla, Callao (a lower-income coastal district in Peru), women from the communities (known as Hope Ladies) are trained to promote cervical cancer screening through HPV self-sampling and guide other women through the screening and eventually treatment process if needed. The Hope Ladies buy the HPV self-sampling kits for 5 PEN per kit ( 1.40 USD) from the Hope Project and sell the kits in their communities at a significantly subsidized price of 10 PEN ( 2.90 USD). They sell the kits door-to-door by leveraging their social networks in their spare time and keep the small profit of the sales (5 PEN per kit [ 1.40 USD]) as an incentive for the wide dissemination of the HPV self-sampling kits to their clients. They provide education about cervical cancer prevention, how to perform HPV self-sampling, and help them seek follow-up care as needed (e.g., encouraging HPV-positive women to go to their public health clinics for triage).

The concept of women's empowerment has been explored as a mediator between social entrepreneurship and change (22), but not in the context of HPV self-sampling. Understanding the relationship between these concepts could be the key to inform future program direction and developing a scalable social entrepreneurship model to increase access to cervical cancer screening. Therefore, we undertook this 
study to 1) evaluate the Hope Ladies' relational and financial empowerment after participating in the social entrepreneurship, and 2) develop a causal pathway to illustrate if and how empowerment improves the effectiveness of the Hope Project intervention.

\section{Methods}

We evaluated the Hope Ladies' experiences of empowerment using parallel mixed-methods (29). In early March 2020, we randomly selected and invited 20 of the 62 Hope Ladies (32\%) to participate in a survey and an individual in-depth interview through Whatsapp. Each participant gave written informed consent in Spanish. Participant characteristics were gathered from the administrative data from the project. The interview and survey were conducted in the participants' homes, without the presence of other family members or program administrators. The data was collected by at least two trained study personnel, one of whom was fluent in Spanish. The study was approved by the International Review Boards of Cayetano Heredia University (\#103900), Duke University (\#2020-0376) and the University of Washington (STUDY00010676).

\section{Quantitative Methods}

The financial empowerment survey questions $(n=4)$ were developed based on the International Center for Research on Women (ICRW)'s economic empowerment indicators (30). The ICRW's framework measures women's economic empowerment by tracking indicators such as control over assets, the agency in decision making, autonomy and mobility, self-confidence and self-efficacy, gender norms, and gender roles within the household. The relational empowerment survey questions $(n=4)$ were developed based on the Relational Leadership Theory (RLT), which shifts the attention away from individuals to the "collective action of interconnected individuals" (31). We used the RLT to examine empowerment in the context of family, social networks, and communities, with the assumption that power is "developed and exercised through relationships" (32). Each survey instrument (available in the supplementary material) was designed to take 10 minutes, prepared in English and translated and reviewed by the study personnel, piloted by the Hope Project administrators, and amended according to their feedback before finalization. All questions were based on a five-point Likert scale. The surveys were administered orally in Spanish by study personnel. We used basic frequencies and proportions to analyze the results of the financial and relational empowerment surveys.

\section{Qualitative Methods}

We performed individual in-depth interviews, following the guide of fourteen questions developed using ICRW's economic empowerment indicators and the RLT (available in the supplementary material). The interviews were designed to take about 30 minutes and were transcribed verbatim in Spanish by an independent contractor fluent in Spanish and a resident of a nearby city.

We conducted a structured deductive content analysis (33). Two authors (MS, MD) independently cleaned the data and organized the pre-determined codes from ICRW framework and relational leadership 
theory into the individual- and community-level sub-categories depicted in the fishbone matrix diagram in Figure 1. Then, codes and constructs were mapped onto the generic categories of resource, agency, and achievements from Kabeer's conceptual model of empowerment, acknowledging that these constructs are not mutually exclusive but rather inter-related (23). We decided to use the three frameworks for the analysis (e.g., ICWR, RLT, and Kabeer's conceptual framework) because the science of defining and measuring women's empowerment is complex and evolving (34-37), and Kabeer's framework has been successfully used to analyze women's empowerment in social entrepreneurship in developing countries $(24,25)$. The two authors (MS and MD) met subsequently to iteratively discuss their individual findings from the qualitative data analysis and discuss discrepancies until reaching consensus. In addition, they discussed how the qualitative and quantitative data converged and diverged to triangulate their findings (38). Salient quotes were translated from Spanish to English by MS and verified by other bilingual authors. Qualitative analysis was performed using NVivo 12 (QRS International, Burlington, MA, USA).

\section{Development of Potential Causal Pathway}

To discover actionable determinants and move beyond identifying barriers and facilitators, we developed an implementation science-based causal pathway that can be used for hypothesis generation and testing in the future. Using the Agile Science-informed method specified by Lewis et al. and the findings of our surveys and interviews, we developed a pathway model for the Hope Project to increase HPV selfsampling kit sales (proximal outcome), thereby increasing cervical cancer screening coverage (distal outcome) (39).

We followed the definition of the mechanism of action, which was the "process or event through which the implementation strategy operates to affect desired implementation outcomes" (39). The cognitive moderator was defined as individual-level perception or attitudes that increase or decrease the level of the influence of the Hope Project. In contrast, the organizational moderator was defined as community-level factors such as culture or widely held beliefs. We also defined pre-conditions, or factors necessary for an implementation mechanism to be activated and the proximal outcome to be realized, in the Hope Project.

\section{Results}

All 20 randomly invited Hope Ladies agreed to participate in the study, and the interviews were scheduled for early March 2020. Overall, the 20 Hope Ladies participated in the individual in-depth interviews.

However, because of unforeseen logistical challenges and sudden country lockdown due to the COVID-19 pandemic during the week of the data collection, some participants were rescheduled and completed the financial $(n=10)$, and relational empowerment $(n=5)$ surveys at a later date in June 2021 virtually. Ultimately, 19 women completed the relational empowerment survey, and 17 women completed the financial empowerment survey completely, from which the analysis was conducted.

The Hope Ladies' ages ranged from 32 to 64 , with a median age of 45 years old, lived in the Ventanilla region for a median of 20 years (range 10-37 years), and had been involved with the Hope Project a 
median of 9 months (range 1 to 12 months) (Table 1). 7 (35\%) were born in the Andean region, 11 (55\%) in the coastal region, and $1(5 \%)$ in the Amazon region. The participants had sold a median of $151 \mathrm{HPV}$ self-sampling kits, with a median profit of 23.50 USD per month (Range: 7.20 to 72.80 USD).

In Table 2, we present the results of the relational and financial surveys. The summary of deductive content analysis of the in-depth interviews is available in the supplementary material with salient quotes from the participants. We present the results organized according to the conceptual framework presented in Figure 1. The survey data has been integrated with the qualitative data with illustrative quotes from the in-depth interviews.

\section{Resources}

Resources could be defined as those conditions that enhance the ability to exercise choice (23). The Hope Ladies described the challenge of managing their roles within the household and working as a Hope Lady and the benefit of peer support within the Hope Project, as well as being recognized as a resource for women's reproductive health in their communities.

\section{Gender norms and roles within the household}

Maintaining roles within the household and working as a Hope Lady: The majority of the Hope Ladies ( $n=15,75 \%)$ mentioned during the interviews that it is difficult for them to manage their time to sell HPV self-sampling kits in their communities due to their various roles in their households, such as childrearing and caregiving. One stated, "I have a baby. When she grows a little more, I don't think I will have any obstacles with the Hope Project," (Hope Lady, age 35), and another stated, "I have my mother-in-law in my care. She needs me to take care of her [...] because she cannot get out of bed. I go [out to sell the kits], but with the thought, 'what if she suddenly falls out of bed,' or I do not know she will urinate on herself. Sometimes I wonder, 'Should I continue [to work as a Hope Lady] or not?' and sometimes I stop [selling the kits]. But my friends [other Hope Ladies] tell me, 'Don't stop, keep going for us."'(Hope Lady, age 33). Another stated, "It's definitely not easy [...] it is a matter of organizing, it is a matter of habit, it is a matter of accustoming the family. It has its consequences, but it is possible to balance." (Hope Lady, age 33). In contrast, others found it easy or manageable to organize their time. For example, one mentioned, "It's not difficult for me [to manage my time] because the issue here is to organize ourselves. If we organize ourselves, everything works out for us." (Hope Lady, age 45). Another emphasized the convenience of setting their own schedule saying, "Without having to have an obligatory schedule, in my free time I can go to work myself." (Hope Lady, age 33).

\section{Relationships at the community-level as the collective identity of Hope Ladies}

Hope Ladies as a resource for the communities: In the relational empowerment survey, all participants responded "agree/totally agree" ( $n=19,100 \%)$ to the question, "would you say that you have been able to help other women in moments of need since the beginning of your Hope Lady journey?" (Table 2). Half of the Hope Ladies interviewed $(n=10,50 \%)$ reported being recognized for their knowledge about cervical 
cancer in their communities and said, "They [the community women] talk to me more because you know in the hospital, they [the doctors] will hardly talk to them like we [Hope Ladies] talk to them." (Hope Lady, age 45).

The camaraderie with other Hope Ladies: Nearly half $(n=9,45 \%)$ of the Hope Ladies commented on enjoying the peer support with other Hope Ladies and stated collaborating with other colleagues helped sell their kits. One said, "We would agree with other colleagues [Hope Ladies], and we would go out in a group because it is less tedious [than] when you are alone." (Hope Lady, age 64). Another person commented they look forward to the growth of the Hope Project, saying, "we are working with the Cayetano [University], so that [the Hope Project] grows and we can amplify the good work." (Hope Lady, age 54).

\section{Agency}

Agency is defined as the capability to define one's goal and act upon it (23). The Hope Ladies reported an increased sense of confidence and efficacy in themselves stemming from increased knowledge about reproductive health and improved communication ability and express themselves. They also discussed changes in behaviors, values, attitudes, and ideologies, such as advocating for their clients (other community women) to make autonomous decisions about HPV self-sampling against male-dominant culture (machismo).

\section{Individual-level self-confidence and self-efficacy}

Improved self-confidence and ability to communicate and express thoughts: All participants agreed $(\mathrm{n}=8$, $42 \%)$ or totally agreed $(n=11,58 \%)$ in the relational empowerment survey that they felt more confident than before working as a Hope Lady because they learned about the female reproductive health system (Table 2). One person mentioned, "If it weren't for this [the Hope Project], I wouldn't even have taken the test," (Hope Lady, age 44$)$. More than half $(n=12,60 \%)$ of the participants reported improved communication abilities to express themselves. One reported, "It has helped me to have more confidence in words, that is, in being able to express myself with confidence what I am talking about." (Hope Lady, age 33). Another emphasized the importance of ongoing support and training by the Hope Project to her and said, "I have lost the shame of communicating with people, because before I was not capable. When I started, I was very shy, but now I have enough skills. I have acquired that with [Hope Project] because of the training that they also give us. They support us in everything that we do, we also consult with them." (Hope Lady, age 46).

Increased knowledge and self-efficacy: All ( $n=20,100 \%)$ of the Hope Ladies said the increased knowledge and education about cervical cancer helped them to make informed decision-making for themselves, as well as other community women. $53 \%(n=10)$ agreed, and $37 \%(n=7)$ totally agreed that they have been able to increase unaccompanied visits to a healthcare provider to meet their personal needs since the beginning of your job as a Hope Lady?" One stated, "It has empowered me, and I have gained a lot of experience [...] It taught me to express myself, to reach the families who are the most in need, and I saw 
that there is a lot of need in the communities that I have visited, and others thank you and tell you, 'Thanks for coming! Thank you for remembering me!' And all that makes your self-esteem rise, and you have more desire to continue working, for them, for them more than anything." (Hope Lady, age 47).

\section{Evolving social order and change in relational dynamics}

Advocating for women against male-dominant culture: Almost all $(n=18,90 \%)$ of the Hope Ladies mentioned male-dominant culture (machismo) in the households as a barrier to selling the HPV selfsampling kits and stated they advocate for community women to make autonomous decisions about their bodies by educating them and sometimes their husbands. A few $(n=3,15 \%)$ Hope Ladies reported clients who buy the HPV self-sampling kits in secret, without informing their husbands. One said, "We are not talking about the test anymore; we talked and encountered different problems. We are like a "heart" doctor. They already believe us [heart] doctors, because they ask us different things. We try to lift the woman so that they are not left saying, 'Oh, I'm going to ask my husband's permission!'" (Hope Lady, age 33). One person reported, "Women are well-trodden [...] I say to them, 'Who is the one who is going to show their body [to the doctor]? Who is the one who is going to get sick? Your husband or you?'[...] There are cultural barriers [...] because the liberation of women is also being imposed!" (Hope Lady, age 64).

The Hope Ladies identified the Hope Project as a source of advocacy against the male-dominant culture, saying, "We help them so that they can become aware that the decision is in themselves, and that we do not depend on anyone. We say, 'We have come alone, and we are going to leave alone, so each one is the owner of what to do and what decisions to make.' And that is what I have learned with Hope Project." (Hope Lady, age 46). Another person said, "The empowerment that [the Hope Project] brings to us, that other institutions cannot, is women's self-realization, their power to decide themselves, not to ask their partner." (Hope Lady, age 48). Although the interviewers did not solicit information about domestic violence, a quarter of all participants $(n=5,25 \%)$ mentioned their clients shared that they sometimes experience it.

\section{Achievements}

Achievement can be seen as the outcome of the resources and agency (23). The Hope Ladies reported an increased sense of financial autonomy and expanded social network since joining the Hope Project.

\section{Control over assets}

Increased economic assets: All $(\mathrm{n}=20,100 \%)$ participants reported that the supplemental income from selling HPV self-sampling kits was economically helpful. One participant responded, "Of course, it has helped me a lot [...] It helps me for my children's bus fares, which is daily for school." (Hope Lady, age 45). Another stated, "Yes, it helps [financially]. It is a job that helps you financially and that you are also helping other people, other women." (Hope Lady, age 51).

\section{Financial autonomy}


Improved financial autonomy: Most participants of the financial empowerment survey ( 16 of $17,94 \%)$ reported that currently, they "always" decide on how to money in their household (Table 2). In contrast, when asked the same question before starting the Hope project, $41 \%$ (7 of 17) responded "always." In the individual interviews, the change in the ability to make financial decisions since working as a Hope Lady was more subtle. One participant who is a single-parent stated, "I'm the one who works. I am a mother and father, I have a daughter, and I am the one who says how much money comes into my house and how much I am going to spend. I try to balance what is my priority." (Hope Lady, age 47). Another stated, "Although I don't [work], I have always tried to solve all the house expenses. [My husband] is the one who contributes." (Hope Lady, age 33).

\section{Relationship as an outcome}

Widened social network and gaining technology skills: In the relational empowerment survey, all participants responded either "agree" $(n=3,16 \%)$ or "totally agree" $(n=16,84 \%)$ that the number of social contacts within and outside the family has increased since working as a Hope Lady (Table 2). One stated, "They [the community women] comment on the program and they look for us, and they call us about this topic [of HPV self-sampling]. They call us, they leave our numbers, and other people who have never met call us, and you get to know more people." (Hope Lady, age 45).

In relation to the widened social network, technology skills development emerged as a significant achievement. Many mentioned they had no to limited experience with social media or cell phones prior to joining the Hope Project. One stated, "I didn't know how to use [a touchscreen phone] at all. And when I joined the Hope Project, it was practically indispensable... [the project members] themselves have taught me to use it, they have taught me to enter the page, to enter the data [...] I have learned everything about technology with the Hope Project, because before I didn't even care to pick up a phone, but now I do." (Hope Lady, age 46). Another stated, "Social networks...the cell phone for me was nothing more like the phone that you go and answer, nothing at all! Now I know, well, I chat everything." (Hope Lady, age 33).

\section{Empowerment as the Mechanism of Action}

We developed a causal pathway model for the Hope Project based on the mixed-methods findings (Figure 2). Empowerment was evident as the predominant causal mechanism to increase HPV self-sampling kit sales and cervical cancer screening in the Hope Project. In this model, the implementation strategy of microfinancing and peer-education operates through the process of Hope Ladies' empowerment to achieve the proximal and distal outcomes. The individual and collective improvement of resources, agency, and achievement, necessary for the mechanism of empowerment to be activated. The perceived value of financial and relational incentive emerged as cognitive moderators, whereas logistical and sociocultural barriers to HPV self-sampling in the community, such as male-dominant culture, were organizational moderators. As the pre-condition for the proximal outcome, the Hope Ladies must have the financial and logistical means of buying and selling HPV self-sampling kits for the sales to increase. 


\section{Discussion}

We evaluated the relational and financial empowerment of women participating in social entrepreneurship called the Hope Project in Peru using surveys and in-depth interviews and created a pathway model to inform future program direction and scaling of this community-based HPV selfsampling intervention. We found that the Hope Ladies individually and collectively experienced meaningful improvement of resources, agency, and achievement in varying degrees and forms, which expanded their capacity to make strategic and meaningful choices in their households and communities. Using a pathway model, we show how HPV self-sampling kit sales are achieved through the empowerment of the Hope Ladies, which function as the mechanism of action for the Hope Project.

There is strong evidence linking women's economic empowerment to improved health outcomes for both women and their families. Benefits include uptake of family planning, improved nutrition, and reduced maternal and child mortality (30). The social entrepreneurship model has been used successfully to incentivize the uptake of health services and behavior change in the context of HIV $(40,41)$, syphilis (42), and malaria (43). Social entrepreneurship programs are uniquely positioned to empower women who are vulnerable to sexually transmitted infections such as HIV due to gender disparity in social structures and relationships, such as income inequality, violence, and educational opportunities $(44,45)$. For example, Haitian women who participated in a microfinance program were less likely to report partner infidelity and more likely to report condom use with their partners than those who did not participate in the program (46). A micro-grant intervention called the SHAZ! Project reported a significant improvement in economic security and decreased HIV risk factors such as transactional sex or gender-based violence among the adolescent female orphans in Zimbabwe (47).

As noted in the conceptual model, resources, agency, and achievements were interrelated and indivisible for the empowerment of the Hope Ladies in our study. The Hope Ladies reported that improved resources in the form of supplemental income improved their ability to participate in financial and household decisions. The recognition of the Hope Ladies as a community resource for reproductive health widened their social network and gave them more social capital. Increased knowledge, self-confidence, and expanded social network empowered the Hope Ladies to see and advocate for the women in their communities by speaking out against the unequal power relations with their spouses, disparate access to healthcare, and fear of stigma in being diagnosed with cervical cancer.

As demonstrated in our causal pathway, the relational and economic empowerment of the Hope Ladies is necessary but not sufficient to produce the pre-conditions of financial and logistical means of buying and selling HPV self-sampling kits. For example, the empowerment of the Hope Ladies alone cannot protect their time against competing household priorities such as caring for another family member. Leveraging the social entrepreneurship structure and increasing their financial incentives would bolster their empowerment and protect the Hope Ladies' time to sell more kits which would modify the effects of the aforementioned contextual moderators. 
Our study has several limitations. Our sample size was small, and the number of respondents varied in some survey questions because the data collection took place during the week Peru closed its borders due to the COVID-19 pandemic. These factors may negatively impact the generalizability of our findings. Secondly, the interviews took place in the participants' homes, which may have biased their responses due to privacy concerns. Although the interviewers were fluent in Spanish and the Hope Project administrators were not present during the interview, the presence of other study personnel may have contributed to social desirability bias. Despite the limitations, we rigorously evaluated the financial and relational empowerment of the Hope Ladies, using multiple well-established conceptual frameworks and mixed-methods.

\section{Conclusions}

In conclusion, the participants in the community-based HPV self-sampling social entrepreneurship experienced improved financial and relational empowerment in the program. More research is needed to test and demonstrate the association between the Hope Ladies' empowerment and cervical cancer screening uptake by community members to scale this intervention to a broader population.

\section{Abbreviations}

HPV human papillomavirus

ICRW International Center for Research on Women

RLT Relational Leadership Theory

\section{Declarations}

\section{Ethics approval and consent to participate}

The study was approved by the International Review Boards of Cayetano Heredia University (\#103900), Duke University (\#2020-0376) and University of Washington (STUDY00010676). All participants gave written consent in Spanish. All methods were carried out in accordance with relevant guidelines and regulations.

\section{Consent for publication}

Not applicable.

\section{Availability of data and materials}

Data sharing is not applicable to this article as no datasets were generated or analyzed during the current study. 


\section{Competing interests}

The authors declare that they have no competing interests

\section{Funding}

This work was supported by the University of Washington School of Nursing and the United States Agency for International Development (USAID-DIV 7200AA19FA00001). All funders had no role in the design, data collection, analysis, interpretation of the study or writing of the manuscript.

\section{Authors' contributions}

MS, PG, RB, and SG made substantial contributions to the conception and the design of the work. MD, $M V, M C$ and $P G$ contributed to data acquisition. MS and MD conducted data analysis, interpretation of the data, and drafted the original manuscript. PG, NR, MK, KA, RB, SI, and SG provided substantial review and revision to the manuscript. All authors read and approved the final manuscript and agreed to be accountable for the author's own contributions.

\section{Corresponding author}

Correspondence to Michelle Shin.

\section{Acknowledgements}

We would like to thank the Hope Project staff for assisting the data collection and participants for taking part in the interviews and surveys.

\section{References}

1. García-Jurado A, Pérez-Barea JJ, Nova RJ. A New Approach to Social Entrepreneurship: A Systematic Review and Meta-Analysis. Sustainability. 2021;13(5).

2. Phillips W, Lee H, Ghobadian A, O'Regan N, James P. Social Innovation and Social Entrepreneurship: A Systematic Review. Group \& Organization Management. 2014;40(3):428-61.

3. Short JC, Moss TW, Lumpkin GT. Research in social entrepreneurship: past contributions and future opportunities. Strategic Entrepreneurship Journal. 2009;3(2):161-94.

4. Bacq S, Janssen F. The multiple faces of social entrepreneurship: A review of definitional issues based on geographical and thematic criteria. Entrepreneurship \& Regional Development. 2011;23(5/6):373-403.

5. Sassmannshausen SP, Volkmann C. A bibliometric based review on social entrepreneurship and its establishment as a field of research. Schumpeter Discussion Papers; 2013.

6. Mosher-Williams R, Association for Research on Nonprofit O, Voluntary A, Mosher-Williams R, Association for Research on Nonprofit O, Voluntary A. Research on social entrepreneurship : 
understanding and contributing to an emerging field. Washington, DC: Washington, DC : Aspen Institute; 2006.

7. Huybrechts B, Nicholls A. Social Entrepreneurship: Definitions, Drivers and Challenges. Wiesbaden: Wiesbaden: Gabler Verlag; 2012. p. 31-48.

8. Volkmann CK, Tokarski KO, Ernst K, Volkmann CK, Tokarski KO, Ernst K. Social entrepreneurship and social business : an introduction and discussion with case studies. Wiesbaden: Wiesbaden : Springer Gabler; 2012.

9. Gupta P, Chauhan S, Paul J, Jaiswal MP. Social entrepreneurship research: A review and future research agenda. Journal of Business Research. 2020;113:209-29.

10. Macke J, Sarate JAR, Domeneghini J, Silva KAd. Where do we go from now? Research framework for social entrepreneurship. Journal of Cleaner Production. 2018;183:677-85.

11. Akbulaev N, Aliyev Y, Ahmadov T. Research models for financing social business: theory and practice. Heliyon. 2019;5(5):e01599.

12. Mair J, Battilana J, Cardenas J. Organizing for Society: A Typology of Social Entrepreneuring Models. Journal of Business Ethics. 2012;111(3):353-73.

13. Mair J, Martí I. Social entrepreneurship research: A source of explanation, prediction, and delight. Journal of World Business. 2006;41(1):36-44.

14. Marshall RS. Conceptualizing the International For-Profit Social Entrepreneur. Journal of business ethics. 2011;98(2):183-98.

15. Zahra SA, Gedajlovic E, Neubaum DO, Shulman JM. A typology of social entrepreneurs: Motives, search processes and ethical challenges. Journal of Business Venturing. 2009;24(5):519-32.

16. Campbell S. Social entrepreneurship: how to develop new social-purpose business ventures. Health care strategic management. 1998;16(5):17-8.

17. Murray RC-G, J; Mulgan, G. The Open Book of Social Innovation: The Young Foundation 2010.

18. Zadek S, Thake S. Send in the social entrepreneurs. New Statesman. 19971997 Jun 20:31.

19. Austin J, Stevenson H, Wei-Skillern J. Social and Commercial Entrepreneurship: Same, Different, or Both? Entrepreneurship Theory and Practice. 2006;30(1):1-22.

20. Chant S. Exploring the feminisation of poverty in relation to womeé s work and home-based enterprise in slums of the Global South. International Journal of Gender and Entrepreneurship. 2014;6:296-316.

21. Lim YW, Chia A. Social Entrepreneurship: Improving Global Health. Jama. 2016;315(22):2393-4.

22. Haugh HM, Talwar A. Linking Social Entrepreneurship and Social Change: The Mediating Role of Empowerment. Journal of Business Ethics. 2016;133(4):643-58.

23. Kabeer N. Resources, Agency, Achievements: Reflections on the Measurement of Women's Empowerment. Development and Change. 1999;30(3):435-64.

24. Kabeer N. Economic Pathways to Women's Empowerment and Active Citizenship: What Does The Evidence From Bangladesh Tell Us? The Journal of Development Studies. 2017;53(5):649-63. 
25. Datta PB, Gailey R. Empowering Women through Social Entrepreneurship: Case Study of a Women's Cooperative in India. Entrepreneurship Theory and Practice. 2012;36(3):569-87.

26. Mair J, Schoen 0 . Successful social entrepreneurial business models in the context of developing economies. International Journal of Emerging Markets. 2007;2(1):54-68.

27. Santos FM. A positive theory of social entrepreneurship. Journal of business ethics. 2012;111(3):335-51.

28. Moran F, Carcamo C, Valderrama M, Garcia PJ. [Preferences and satisfaction towards a screening program with self-administered human papilloma virus detection tests]. Rev Peru Med Exp Salud Publica. 2017;34(2):228-32.

29. Shorten A, Smith J. Mixed methods research: expanding the evidence base. Evidence Based Nursing. 2017;20(3):74.

30. Golla AM, Malhotra A, Nanda P, Mehra R. Understanding and Measuring Women's Economic Empowerment: Definition, Framework and Indicators. International Center for Research on Women; 2018.

31. Sklaveniti C. Relational Leadership Theory. In: Farazmand A, editor. Global encyclopedia of public administration, public policy, and governance. Cham, Switzerland: Cham, Switzerland : Springer International Publishing AG; 2018. p. 5417-20.

32. Christens BD. Toward Relational Empowerment. American Journal of Community Psychology. 2012;50(1):114-28.

33. Elo $S$, Kyngas $H$. The qualitative content analysis process. J Adv Nurs. 2008;62(1):107-15.

34. Manuere F, Phiri N. A Literature Review of Women Empowerment and Development in Zimbabwe: A look at New Insights and Perspectives. Journal of Public Administration and Governance. 2018;8:57.

35. Dekker $\mathrm{M}$, editor Promoting gender equality and female empowerment : a systematic review of the evidence on property rights, labour markets, political participation and violence against women2013.

36. O'Hara C, Clement F. Power as agency: A critical reflection on the measurement of women's empowerment in the development sector. World Development. 2018;106:111-23.

37. Leder S. Linking Women's Empowerment and their Resilience. CGIAR Research Program on Water, Land and Ecosystems; 2016.

38. Palinkas LA, Aarons GA, Horwitz S, Chamberlain P, Hurlburt M, Landsverk J. Mixed method designs in implementation research. Adm Policy Ment Health. 2011;38(1):44-53.

39. Lewis CC, Klasnja P, Powell BJ, Lyon AR, Tuzzio L, Jones S, et al. From Classification to Causality: Advancing Understanding of Mechanisms of Change in Implementation Science. Frontiers in Public Health. 2018;6(136).

40. Sherer RD, Jr., Bronson JD, Teter CJ, Wykoff RF. Microeconomic loans and health education to families in impoverished communities: implications for the HIV pandemic. J Int Assoc Physicians AIDS Care (Chic). 2004;3(4):110-4. 
41. Viravaidya M, Wolf RC, Guest P. An assessment of the Positive Partnership Project in Thailand: key considerations for scaling-up microcredit loans for HIV-positive and negative pairs in other settings. Global public health. 2008;3(2):115-36.

42. Tucker JD, Muessig KE, Cui R, Bien CH, Lo EJ, Lee R, et al. Organizational characteristics of HIV/syphilis testing services for men who have sex with men in South China: a social entrepreneurship analysis and implications for creating sustainable service models. BMC Infect Dis. 2014;14:601.

43. Allen LK, Hetherington E, Manyama M, Hatfield JM, van Marle G. Using the social entrepreneurship approach to generate innovative and sustainable malaria diagnosis interventions in Tanzania: a case study. Malar J. 2010;9:42-.

44. Sumartojo E. Structural factors in HIV prevention: concepts, examples, and implications for research. AIDS (London, England). 2000;14.

45. Auerbach JD, Parkhurst JO, Cáceres CF. Addressing social drivers of HIV/AIDS for the long-term response: Conceptual and methodological considerations. Global public health. 2011;6(sup3):S293S309.

46. Rosenberg MS, Seavey BK, Jules R, Kershaw TS. The role of a microfinance program on HIV risk behavior among Haitian women. AIDS Behav. 2011;15(5):911-8.

47. Dunbar MS, Kang Dufour M-S, Lambdin B, Mudekunye-Mahaka I, Nhamo D, Padian NS. The SHAZ! Project: Results from a Pilot Randomized Trial of a Structural Intervention to Prevent HIV among Adolescent Women in Zimbabwe. PloS one. 2014;9(11):e113621.

\section{Tables}

Table 1. Characteristics of the Interview Participants $(\mathrm{N}=20)$

\begin{tabular}{|ll|}
\hline Characteristics & Median (Range) \\
\hline Age (years) & $45(32-64)$ \\
\hline Residence in the catchment area (years) & $20(10-37)$ \\
\hline Period of involvement with the Hope Project (months) & $9(1-12)$ \\
\hline Number of kits sold & $151(10-610)$ \\
\hline Average profit per month (in USD) * & $23.50(7.20-72.80)$ \\
\hline
\end{tabular}

* Calculated by multiplying the total number of kits sold up to March 2020 by the kit cost ( 1.40 USD) and dividing by total months of HPV self-sampling sales

Table 2. Relational and Financial Empowerment Survey Results 


\section{Relational Empowerment}

\section{Question}

Number of Responses

Responses

Would you say that your number of social contacts within and outside the family has increased since the beginning of your Hope lady journey?

$\begin{array}{lll}\mathrm{N}=19 & \begin{array}{l}\text { Totally } \\ \text { disagree }\end{array} & 0 \\ & \text { Disagree } & 0\end{array}$

$$
\text { Agree }
$$

Totally

agree

Would you say that you have been able to help other women in moments of need since the beginning of your Hope lady journey?

\begin{tabular}{ll}
$\mathrm{N}=19 \quad \begin{array}{l}\text { Totally } \\
\text { disagree }\end{array}$ \\
\cline { 2 - 2 } & Disagree
\end{tabular}

0

Agree

Totally agree

Since becoming a Hope Lady, would you say that you have been able to visit the health care provider to meet your personal needs without your family members or friends accompanying you more easily?

\begin{tabular}{|c|c|c|}
\hline \multirow[t]{4}{*}{$N=19$} & $\begin{array}{l}\text { Totally } \\
\text { disagree }\end{array}$ & $\begin{array}{l}0 \\
(0)\end{array}$ \\
\hline & Disagree & $\begin{array}{l}2 \\
(14)\end{array}$ \\
\hline & Agree & $\begin{array}{l}10 \\
(53)\end{array}$ \\
\hline & $\begin{array}{l}\text { Totally } \\
\text { agree }\end{array}$ & $\begin{array}{l}7 \\
(37)\end{array}$ \\
\hline \multirow[t]{4}{*}{$N=19$} & $\begin{array}{l}\text { Totally } \\
\text { disagree }\end{array}$ & $\begin{array}{l}0 \\
(0)\end{array}$ \\
\hline & Disagree & $\begin{array}{l}0 \\
(0)\end{array}$ \\
\hline & Agree & $\begin{array}{l}8 \\
(42)\end{array}$ \\
\hline & $\begin{array}{l}\text { Totally } \\
\text { agree }\end{array}$ & $\begin{array}{l}11 \\
(58)\end{array}$ \\
\hline
\end{tabular}

Would you say that you have felt confident because of learning about your reproductive health and how to prevent certain diseases compared to starting your job Hope lady? 
Currently, do you decide how to spend money in your household?

$\mathrm{N}=17 \quad$ Always

\begin{tabular}{ll}
\hline Sometimes & 0 \\
& $(0)$ \\
\hline Rarely & 1
\end{tabular}

Never

In the past before joining the Hope Project, did you decide how to $\quad \mathrm{N}=17$

spend money in your household?

\begin{tabular}{ll} 
Always & 7 \\
& $(41)$ \\
\hline Sometimes & 6 \\
& $(35)$ \\
& 3 \\
Rarely & $(18)$ \\
& 1 \\
\hline Never & 1
\end{tabular}

Currently, are you allowed to comment on the purchase of large domestic assets in the household?
$N=17$

Ne17

\begin{tabular}{ll} 
Always & 14 \\
& $(82)$ \\
\hline Sometimes & 1 \\
& $(6)$ \\
Rarely & 2 \\
& $(12)$ \\
\hline Never & 0 \\
\hline
\end{tabular}

(0)

In the past before joining Hope project, were you allowed to comment on the purchase of large domestic assets in the household?
$N=17$

Always

9

Sometimes

Rarely

Never

\section{Figures}




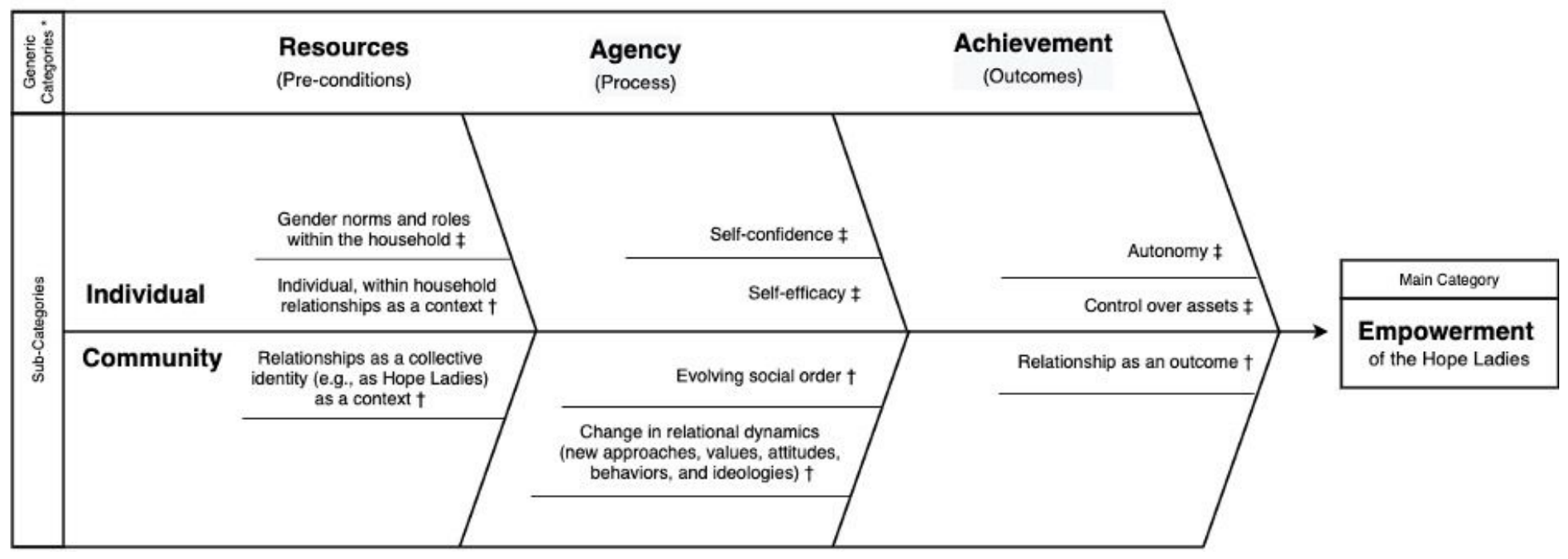

\section{Figure 1}

Conceptual Framework for Qualitative Analysis * Constructs from Kabeer's conceptual framework of empowerment $†$ Pre-determined codes about the Hope Ladies' relational empowerment, derived from Relational Leadership Theory ¥ Pre-determined codes about the Hope Ladies' economic empowerment, derived from International Center for Research on Women

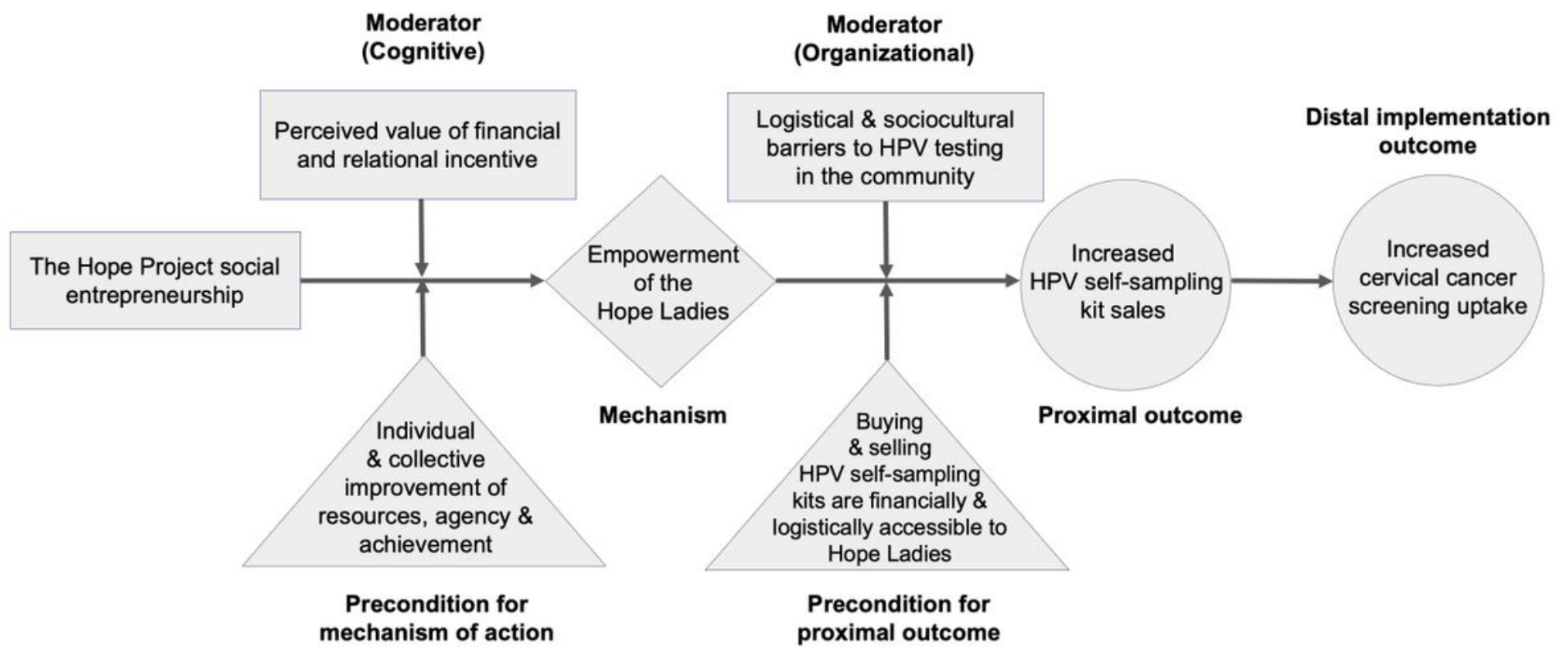

Figure 2

Empowerment as the Mechanism of Action for the Hope Project 


\section{Supplementary Files}

This is a list of supplementary files associated with this preprint. Click to download.

- Additionallnformation.docx 